\title{
Atomic Absorption Spectrometry of Acidic Pharmaceutical Constituents by Precipitation Using Co (II), Cd (II) and Mn (II)
}

\author{
Hesham Salem*, Magda El-Maamli** and Abdalla Shalaby** \\ *Analytical Chemistry Department, Faculty of Pharmacy, Minia \\ University, Minia, Egypt. \\ ${ }^{* *}$ Analytical Chemistry Department, Faculty of Pharmacy, Zagazig \\ University, Zagazig, Egypt.
}

\section{Abstract}

Simple and accurate methods are described for the quantitative determination of flufenamic acid, mefenamic acid and tranexamic acid utilizing precipitation reactions with cobalt, cadmium and manganese. The acidic drugs were precipitated from their neutral alcoholic solutions with cobalt sulphate, cadmium nitrate or manganese chloride standard solutions followed by direct determination of the ions in the precipitate or indirect determination of the ions in the filtrate by atomic absorption spectroscopy. The optimum conditions for precipitation were carefully studied. The molar ratio of the reactants was ascertained. Statistical analysis of the results compared to the results of the official methods revealed equal precision and accuracy. The suggested procedures were applied for determining flufenamic acid, mefenamic acid and tranexamic acid in pharmaceutical preperations as well and proved validity.

Key Words: Cobalt, Cadmiun, Manganese, Flufenamic acid, Mefenamic acid, Tranexamic acid, Atomic Absorption Spectrophotometry. 


\section{Introduction}<smiles>O=C(O)c1ccccc1Nc1cccc(C(F)(F)F)c1</smiles>

Flufenamic acid

Flufenamic acid is a non steroidal anti-inflammatory, antipyretic drug with analgesic properties. Its chemical structure is $\mathrm{N}-(\alpha \alpha \alpha$-Trifluoro-m-tolyl)anthranilic acid.

Several techniques were used for determination of flufenamic acid such as fluorometric ${ }^{1}$, chromatographic ${ }^{2}$ and spectrophotometric ${ }^{3-7}$ ones.<smiles>Cc1cccc(Nc2ccccc2C(=O)O)c1C</smiles>

Mefenamic acid

Mefenamic acid is anti-inflammatory, antipyretic drug with analgesic properties. Its chemical structure is $\mathrm{N}-(2,3$ xylyl)anthranilic acid.

Several techniques were used for the determination of this drug such as polarographic ${ }^{8,9}$, fluorometric ${ }^{10}$, chromatographic ${ }^{11}$ and spectrophotometric ${ }^{12-15}$ techniques.

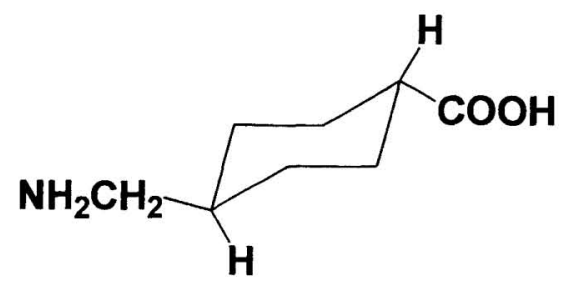

Tranexamic acid

Tranexamic acid [4-(Amino methyl) cyclohexanecarboxylic acid] is an antifibrinolytic agent used mainly in the treatment and prophylaxis of haemorrhage associated with excessive fibrinolysis. 
Several techniques were used for the determination of this drug, include fluorometric ${ }^{16}$, chromatographic ${ }^{17}$ and spectrophotometric ${ }^{18,19}$ analysis.

The present work represents the utilization of cobalt, cadmium and manganese as reagents for the determination of flufenamic acid, mefenamic acid and tranexamic acid by direct and indirect A.A.S. measurements. The methods proved to be very sensitive and accurate for the determination of these compounds in pharmaceutical preparations.

\section{Instruments:}

\section{Experimental}

1-Shimadzu Atomic Absorption, Flame Spectrophotometr.

2- Shimadzu UV 1601, UV-Visible spectrophotometer (Tokyo, Japan).

\section{Materials and Reagents:}

Flufenamic acid from Alex.Co.,Egypt,mefenamic acid from Park-Davis $\mathrm{Co}$. and tranexamic acid from Pharmacia AB, Stockholm, Sweden were used. Pinox capsules were obtained from Alex. Co., Egypt, labeled to contain $100 \mathrm{mg}$ flufenamic acid per each capsule. Ponstan capsules and syrup were obtained from Nile Co., Egypt, labeled to contain $250 \mathrm{mg}$ and $50 \mathrm{mg}$ mefenamic acid per each capsule or $5 \mathrm{ml}$ syrup, respectively. Cyklokapron tablets and ampoules were obtained from Pharmacia $A B$, Stockholm Sweden, labeled to contain $500 \mathrm{mg}$ and 100 $\mathrm{mg}$ tranexamic acid per each tablet or $1 \mathrm{ml}$ ampoule, respectively. Stocks flufenamic acid, mefenamic acid and tranexamic acid solutions were prepared by dissolving 100 $\mathrm{mg}, 80 \mathrm{mg}$ and $100 \mathrm{mg}$ in $50 \mathrm{ml}$ alcohol, respectively. The solutions were rendered neutral or slightly alkaline $(\mathrm{pH} 7.3$

- 8.2) with $0.1 \mathrm{~N}$ sodium hydroxide and then complete to $100 \mathrm{ml}$ with redistilled deionized water. $0.01 \mathrm{M}$ of 
flufenamic acid or mefenamic acid or tranexamic acid working solutions is used for Job's method of continuous variation ${ }^{20}$.

\section{Procedures for Authentic Drugs:}

Atomic absorption spectrophotometry utilizing cobalt :

To aliquots of stock solutions (equivalent to 1.2-48.0 $\mathrm{mg}$ flufenamic acid, 3.5-70.6 mg mefenamic acid and 2.4$36.0 \mathrm{mg}$ tranexamic acid), five $\mathrm{mls}$ of cobalt sulphate solution was added. Solutions were well shaken, filtered (Whatman No.44) and the precipitates were washed with redistilled deionized water till free of cobalt.

\section{Direct method}

The precipitates obtained above were dissolved in a minimum amount of dilute ammonia solution and completed to $25 \mathrm{ml}$ with redistilled deionized water. Two mls of the resulting solutions was diluted to $25 \mathrm{mls}$ with redistilled deionized water.

\section{Indirect method}

The filtrates and washings were collected in $100 \mathrm{ml}$ volumetric flasks and completed to volume with redistilled deionized water. Ten mls of the resulting solution was diluted to $100 \mathrm{ml}$ with redistilled deionized water.

A blank (omitting addition of drugs) was prepared and absorbance was measured at the flaming conditions; wavelength $240.7 \mathrm{~nm}$, lamp current $6 \mathrm{~mA}$, slit width $3.8 \mathrm{~A}$ air flow rate $101 / \mathrm{min}$ and acetylene flow rate $2.51 / \mathrm{min}$. Cobalt concentration was calculated from a calibration curve.

\section{Atomic absorption spectrophotometry utilizing cadmium:}

To aliquots of stock solutions (equivalent to 1.2-48.0 mg flufenamic acid, 3.5-70.6 mg mefenamic acid and 2.4$36.0 \mathrm{mg}$ tranexamic acid), five mls of cadmium nitrate solution was added. Solutions were well shaken, filtered (whatman No.44) and the precipitates were washed with redistilled deionized water till free of cadmium. 


\section{Direct method}

The precipitates obtained above were dissolved in a minimum amount of dilute ammonia solution and completed to $25 \mathrm{ml}$ with redistilled deionized water. Two $\mathrm{mls}$ of the resulting solutions was diluted to $25 \mathrm{mls}$ with redistilled deionized water.

\section{Indirect method}

The filtrates and washings were collected in $100 \mathrm{ml}$ volumetric flasks and completed to volume with redistilled deionized water. Ten $\mathrm{mls}$ of the resulting solution was diluted to $100 \mathrm{ml}$ with redistilled deionized water.

A blank (omitting addition of drugs) was prepared and absorbance was measured at the flaming conditions; wavelength $316.2 \mathrm{~nm}$, lamp current $6 \mathrm{~mA}$, slit width $1.9 \mathrm{~A}$, air flow rate $101 / \mathrm{min}$ and acetylene flow rate $2.51 / \mathrm{min}$.

Cadmium concentration was calculated from a calibration curve.

Atomic absorption spectrophotometry utilizing manganese:

To aliquots of stock solutions (equivalent to 1.2-48.0 $\mathrm{mg}$ flufenamic acid, 3.5-70.6 mg mefenamic acid and 2.4$36.0 \mathrm{mg}$ tranexamic acid), five $\mathrm{mls}$ of manganese chloride solution was added. Solutions were well shaken, filtered (whatman No.44) and the precipitates were washed with redistilled deionized water till free of manganese.

\section{Direct method}

The precipitates obtained above were dissolved in a minimum amount of dilute ammonia solution and completed to $25 \mathrm{ml}$ with redistilled deionized water. Two mls of the resulting solutions was diluted to $25 \mathrm{mls}$ with redistilled deionized water.

\section{Indirect method}

The filtrates and washings were collected in $100 \mathrm{ml}$ volumetric flasks and completed to volume with redistilled deionized water. Ten $\mathrm{mls}$ of the resulting solution was diluted to $100 \mathrm{ml}$ with redistilled deionized water. 
A blank (omitting addition of drugs) was prepared and absorbance was measured at the flaming conditions; wavelength $289.1 \mathrm{~nm}$, lamp current $7 \mathrm{~mA}$, slit width $1.9 \mathrm{~A}$, air pressure $101 / \mathrm{min}$ and acetylene flow rate $2.61 / \mathrm{min}$. Manganese concentration was calculated from a calibration curve.

\section{Procedures for assay of pharmaceutical prepar- ations:}

For tablets:

Twenty tablets of Cyclokapron were weighed and finely powdered. The stock solution was prepared by dissolving an amount of powder equivalent to $100 \mathrm{mg}$ tranexamic acid in $100 \mathrm{~mL}$ double-distilled deionized water. The stock solutions were prepared as that in materials and reagents and completed as before.

\section{For ampoules:}

One $\mathrm{ml}$ aliquots of Cyklokapron ampoule (equivalent to $100 \mathrm{mg}$ tranexamic acid) was prepared as stated in tablets stock solution. The stock solutions were prepared as that in materials and reagents and completed as before.

\section{For capsules:}

Twenty capsules of Ponstan or Pinox were weighed and finely powdered. The stock solution was prepared by dissolving an amount of powder equivalent to $80 \mathrm{mg}$ mefenamic acid and $100 \mathrm{mg}$ flufenamic, respectively, in $100 \mathrm{~mL}$ double-distilled deionized water. The stock solutions were prepared as that in materials and reagents and completed as before.

\section{For syrup:}

An aliquots equivalent to $80 \mathrm{mg}$ of mefenamic acid was pipetted into a $100 \mathrm{ml}$ volumetric flask, $40 \mathrm{ml}$ ethanol was added and shaked for $5 \mathrm{~min}$. The solution was rendered neutral ( $\mathrm{pH} 7.0-7.6)$ with $0.1 \mathrm{~N}$ sodium hydroxide, then filtered in a $100 \mathrm{ml}$ volumetric flask and completed to 
volume with redistilled deionized water. The specified amount of the metal solution was added to $5 \mathrm{mls}$. aliquots of the resulting solution and then completed as before.

\section{Results and Discussion}

Neutral alcoholic solutions of mefenamic acid, flufenamic acid and tranexamic acid give coagulated precipitate with cobalt sulphate or cadmium nitrate or manganese chloride. The precipitates form the basis of micro-quantitative determination of the used drugs. The metal ions content can be determined either directly in the precipitate or indirectly in the filtrate by atomic absorption spectrophotomerty (Tables 1-3).

\section{Table 1. Determination of flufenamic acid by the Proposed A.A.S. methods compared to the official method.}

\begin{tabular}{|c|c|c|c|c|c|c|c|}
\hline \multicolumn{7}{|c|}{ A.A.S. } & \multirow{3}{*}{$\begin{array}{l}\text { Official } \\
\text { method }\end{array}$} \\
\hline \multicolumn{3}{|c|}{$\mathrm{Co}^{2+}$ method } & \multicolumn{2}{|c|}{$\mathrm{Cd}^{2+}$ method } & \multicolumn{2}{|c|}{$\mathrm{Mn}^{2+}$ method } & \\
\hline & Direct & Indirect & Direct & Indirect & Direct & Indirect & \\
\hline$X \pm S . D$. & $99.1 \pm 0.47$ & $99.2 \pm 0.44$ & $99.2 \pm 0.40$ & $99.2 \pm 0.49$ & $99.3 \pm 0.24$ & $98.9 \pm 0.40$ & $99.00 \pm 0.45$ \\
\hline $\mathrm{N}$ & & & & 8 & 8 & 8 & 8 \\
\hline v & 0.22 & 0.19 & 016 & 0.24 & 0.17 & 0.16 & 0.20 \\
\hline$t$ & 0.53 & 0.84 & 0.76 & 0.93 & 1.46 & 0.24 & $(2.14)^{\star}$ \\
\hline $\mathrm{F}$ & 1.10 & 1.05 & 1.25 & 1.20 & 1.18 & 1.25 & $(3.79)^{\star}$ \\
\hline
\end{tabular}


Table 2. Determination of mefenamic acid by the proposed A.A.S. methods compared to the official method.

\begin{tabular}{|c|c|c|c|c|c|c|c|}
\hline \multicolumn{7}{|c|}{ A.A.S. } & \multirow{3}{*}{$\begin{array}{l}\text { Official } \\
\text { method }\end{array}$} \\
\hline & \multicolumn{2}{|c|}{$\mathrm{Co}^{2+}$ method } & \multicolumn{2}{|c|}{$\mathrm{Cd}^{2+}$ method } & \multicolumn{2}{|c|}{$\mathrm{Mn}^{2+}$ method } & \\
\hline & Direct & Indirect & Direct & Indirect & Direct & Indirect & \\
\hline $\begin{array}{l}X \pm S . D \\
N \\
V \\
t \\
F\end{array}$ & $\begin{array}{c}99.5 \pm 0.27 \\
8 \\
0.07 \\
0.16 \\
1.17\end{array}$ & $\begin{array}{c}99.5 \pm 0.20 \\
8 \\
0.04 \\
0.27 \\
1.50\end{array}$ & $\begin{array}{c}99.5 \pm 0.19 \\
8 \\
0.04 \\
0.18 \\
1.50\end{array}$ & $\begin{array}{c}99.4 \pm 0.23 \\
8 \\
0.05 \\
0.35 \\
1.20\end{array}$ & $\begin{array}{c}99.5 \pm 0.41 \\
8 \\
0.17 \\
0.41 \\
1.47\end{array}$ & $\begin{array}{c}99.5 \pm 0.40 \\
8 \\
0.16 \\
0.18 \\
1.56\end{array}$ & $\begin{array}{c}99.48 \pm 0.25 \\
8 \\
0.06 \\
(2.14)^{*} \\
(3.79)^{*}\end{array}$ \\
\hline $\begin{array}{l}{ }^{*} \mathrm{P}= \\
\text { Tabl }\end{array}$ & $\begin{array}{l}\text { 3. De } \\
\text { pr } \\
\text { of }\end{array}$ & $\begin{array}{l}\text { termina } \\
\text { oposed } \\
\text { ficial me }\end{array}$ & $\begin{array}{l}\text { tion of } \\
\text { A.A.S. } \\
\text { thod. }\end{array}$ & $\begin{array}{l}\text { tranexa } \\
\text { method }\end{array}$ & $\begin{array}{l}\text { imic aci } \\
\text { is comp }\end{array}$ & $\begin{array}{l}\text { id by th } \\
\text { pared to }\end{array}$ & the \\
\hline
\end{tabular}

\begin{tabular}{|c|c|c|c|c|c|c|c|}
\hline \multicolumn{3}{|c|}{$\mathrm{Co}^{2+}$ method } & \multicolumn{2}{|c|}{$\mathrm{Cd}^{2+}$ method } & $\mathrm{Mn}^{2+}$ methoo & \multirow[b]{2}{*}{ Indirect } & \multirow{2}{*}{$\begin{array}{l}\text { Official } \\
\text { method }\end{array}$} \\
\hline & Direct & Indirect & Direct & Indirect & Direct & & \\
\hline$X \pm S . D$. & . $100.1 \pm 0.47$ & $99.99 \pm 0.98$ & $100.2 \pm 1.41$ & $99.9 \pm 1.0110$ & $.3 \pm 1.42$ & $100.2 \pm 1.391$ & $00.2 \pm 1.37$ \\
\hline$N$ & & 8 & 8 & 8 & 8 & 8 & \\
\hline V & 0.22 & 2.07 & 1.99 & 1.93 & 2.02 & 1.93 & 1.88 \\
\hline$t$ & 0.16 & 0.30 & 0.04 & 0.32 & 0.14 & 0.05 & $(2.14)$ \\
\hline $\mathrm{F}$ & 2.91 & 1.51 & 1.06 & 1.03 & 1.07 & 1.03 & $(3.79)^{\star}$ \\
\hline
\end{tabular}

${ }^{*} P=0.05$

Addition of the recommended amount of alcohol is to solubilize the drug and to help coagulation of the precipitate, but larger volumes of alcohol must be avoided otherwise it will solubilize the formed precipitate itself. 
Concerning the effect of $\mathrm{pH}$ on precipitation, buffer solutions covering the acid to the alkaline range have been tried. Acid media have a solubilizing effect on the precipitate leading to lower results for the direct technique and higher ones for the indirect technique while alkali media precipitate the metal as its oxide or hydroxide leading to higher results for the direct technique. The optimun $\mathrm{pH}$ was found to be neutral or slightly alkaline $(\mathrm{pH}$ 7.1-8.1).

Considering metal ion concentration effect on precipitation, $5 \mathrm{ml}$ of the precipitating solutions were found to be sufficient for complete precipitation.

Regarding the temperature effect on precipitation, room temperature was found to be the most efficient. Higher temperatures lead to solubilizing effect on the precipitate producing lower results for the direct technique and higher ones for the indirect technique.

Concerning the stoichiometric relationships, the Job's method of continuous variation ${ }^{20}$ indicated a molar ratios are $1: 2$ (drug to metal).

Statistical analysis of the results obtained by the proposed methods compared with those of the official methods ${ }^{18}$ are given in tables $1,2 \& 3$ at $95 \%$ confidence level, the calculated $t$ and $F$ values do not exceed the tabulated ones, revealing equal precision and accuracy.

In order to prove the validity and applicability of the proposed methods, Pinox capsules containing flufenamic acid, Ponstan capsules and syrup containing mefenamic acid and Cyklokapron tablets and ampoules containing tranexamic acid, were analyzed by the proposed methods. The results obtained compared with the official methods ${ }^{18}$ showed high degree of accuracy and reproducibility (Tables 4-8). 
Table 4. Determination of flufenamic acid in Pinox capsules by A.A.S. methods compared to the official method.

\begin{tabular}{|c|c|c|c|c|c|c|c|}
\hline \multicolumn{7}{|c|}{ A.A.S. } & \multirow{3}{*}{$\begin{array}{l}\text { Official } \\
\text { method }\end{array}$} \\
\hline & \multicolumn{2}{|c|}{$\mathrm{Co}^{2+}$ method } & \multicolumn{2}{|c|}{$\mathrm{Cd}^{2+}$ method } & \multicolumn{2}{|c|}{$\mathrm{Mn}^{2+}$ method } & \\
\hline & Direct & Indirect & Direct & Indirect & Direct & Indirect & \\
\hline$X \pm S . D$. & $99.0 \pm 0.40$ & $99.1 \pm 0.39$ & $99.2 \pm 0.47$ & $98.9 \pm 0.39$ & $98.8 \pm 0.24$ & $99.4 \pm 0.18$ & $99.00 \pm 0.45$ \\
\hline$N$ & & & & 6 & 6 & & 6 \\
\hline V & 0.16 & 0.15 & 0.22 & 0.15 & 0.06 & 0.23 & 0.20 \\
\hline$t$ & 0.00 & 0.41 & 0.75 & 0.41 & 0.96 & 1.50 & $(3.58)^{\star}$ \\
\hline $\mathrm{F}$ & 1.25 & 1.33 & 1.10 & 1.33 & 3.33 & 1.15 & $(4.28)^{\star}$ \\
\hline
\end{tabular}

Table 5. Determination of mefenamic acid in Pnstan syrup by A.A.S. methods compared to the official method.

\begin{tabular}{|c|c|c|c|c|c|c|c|}
\hline \multicolumn{7}{|c|}{ A.A.S. } & \multirow{3}{*}{$\begin{array}{l}\text { Official } \\
\text { method }\end{array}$} \\
\hline & \multicolumn{2}{|c|}{$\mathrm{Co}^{2+}$ method } & \multicolumn{2}{|c|}{$\mathrm{Cd}^{2+}$ method } & \multicolumn{2}{|c|}{$\mathrm{Mn}^{2+}$ method } & \\
\hline & Direct & Indirect & Direct & Indirect & Direct & Indirect & \\
\hline$X \pm S . D$. & $98.9 \pm 0.50$ & $98.8 \pm 0.50$ & $99.0 \pm 0.37$ & $99.1 \pm 0.43$ & $99.3 \pm 0.40$ & $99.0 \pm 0.40$ & $99.48 \pm 0.25$ \\
\hline $\mathrm{N}$ & 6 & 6 & 6 & 6 & 6 & 6 & 6 \\
\hline $\mathrm{v}$ & 0.25 & 0.25 & 0.14 & 0.18 & 0.16 & 0.16 & 0.06 \\
\hline$t$ & 2.57 & 3.02 & 2.60 & 1.88 & 0.94 & 1.12 & $(3.58)^{\star}$ \\
\hline $\mathrm{F}$ & 4.16 & 4.16 & 2.33 & 3.00 & 2.67 & 2.67 & $(4.28)^{\star}$ \\
\hline
\end{tabular}

${ }^{*} P=0.05$ 
Table 6. Determination of mefenamic acid in Ponstan capsules by A.A.S. methods compared to the official method.

\begin{tabular}{|c|c|c|c|c|c|c|c|}
\hline \multicolumn{7}{|c|}{ A.A.S. } & \multirow{3}{*}{$\begin{array}{l}\text { Official } \\
\text { method }\end{array}$} \\
\hline & \multicolumn{2}{|c|}{$\mathrm{Co}^{2+}$ method } & \multicolumn{2}{|c|}{$\mathrm{Cd}^{2+}$ method } & \multicolumn{2}{|c|}{$\mathrm{Mn}^{2+}$ method } & \\
\hline & Direct & Indirect & Direct & Indirect & Direct & Indirect & \\
\hline$X \pm S . D$ & D. $99.7 \pm 0.49$ & $99.1 \pm 0.40$ & $99.0 \pm 0.37$ & $99.3 \pm 0.33$ & $99.3 \pm 0.44$ & $99.2 \pm 0.49$ & $99.48 \pm 0.25$ \\
\hline $\mathrm{N}$ & 6 & 6 & 6 & 6 & 6 & 6 & 6 \\
\hline V & 0.24 & 0.16 & 0.14 & 0.11 & 0.19 & 0.24 & 0.06 \\
\hline$t$ & 0.98 & 1.99 & 2.60 & 1.07 & 0.71 & 1.24 & (3.58) \\
\hline $\mathrm{F}$ & 4.00 & 2.67 & 2.33 & 1.83 & 3.16 & 4.00 & $(4.28)^{\star}$ \\
\hline
\end{tabular}

${ }^{*} \mathrm{P}=0.05$

Table 7. Determination of tranexamic acid in Cycklokapron ampoules by A.A.S. methods compared to the official method.

A.A.S.

\begin{tabular}{ccccc}
\hline $\mathrm{Co}^{2+}$ method & $\mathrm{Cd}^{2+}$ method & $\mathrm{Mn}^{2+}$ method & $\begin{array}{c}\text { Official } \\
\text { method }\end{array}$ \\
\hline Direct & Indirect & Direct & Indirect & Direct Indirect
\end{tabular}

$X \pm$ S.D. $99.7 \pm 0.69100 .1 \pm 0.98 \quad 100.1 \pm 0.87 \quad 100.3 \pm 1.01 \quad 100.3 \pm 1.0099 .7 \pm 0.99 \quad 100.2 \pm 1.37$

\begin{tabular}{cccccccc}
$\mathrm{N}$ & 6 & 6 & 6 & 6 & 6 & 6 & 6 \\
$\mathrm{~V}$ & 0.48 & 0.96 & 0.76 & 1.02 & 1.00 & 0.98 & 1.88 \\
$\mathrm{t}$ & 0.77 & 0.15 & 0.15 & 0.14 & 0.14 & 0.72 & $(3.58)$ \\
$\mathrm{F}$ & 3.92 & 1.96 & 2.47 & 1.84 & 1.88 & 1.92 & $(4.28)^{\star}$ \\
\hline
\end{tabular}

${ }^{*} \mathrm{P}=0.05$ 
Table 8. Determination of tranexamic acid in Cycklokapron tablets by A.A.S. methods compared to the official method.

\begin{tabular}{|c|c|c|c|c|c|c|c|}
\hline \multicolumn{7}{|c|}{ A.A.S. } & \multirow{3}{*}{$\begin{array}{l}\text { Official } \\
\text { method }\end{array}$} \\
\hline & \multicolumn{2}{|c|}{$\mathrm{Co}^{2+}$ method } & \multicolumn{2}{|c|}{$\mathrm{Cd}^{2+}$ method } & \multirow{2}{*}{\multicolumn{2}{|c|}{$\frac{\mathrm{Mn}^{2+} \text { method }}{\text { Direct Indirect }}$}} & \\
\hline & Direct & Indirect & Direc & Indirect & & & \\
\hline$X \pm S . D$. & $99.9 \pm 1.40$ & $100.0 \pm 1.39$ & $100.3 \pm 1.42$ & $100.1 \pm 1.4110$ & $0.0 \pm 0.851$ & $100.1 \pm 0.74$ & $100.2 \pm 1.37$ \\
\hline$N$ & 6 & 6 & 6 & 6 & 6 & 6 & 6 \\
\hline V & 1.18 & 1.18 & 1.19 & 1.18 & 0.92 & 0.86 & 1.88 \\
\hline$t$ & 0.42 & 0.28 & 0.14 & 0.14 & 0.29 & 0.15 & $(3.58)^{*}$ \\
\hline $\mathrm{F}$ & 1.59 & 1.59 & 1.58 & 1.59 & 2.04 & 2.19 & $(4.28)^{\star}$ \\
\hline
\end{tabular}

In conclusion, the proposed methods can be considered to be sensitive and selective for routine analysis of mefenamic acid, flufenamic acid and tranexamic acid either in raw materials or in dosage forms.

\section{References}

1. Winkinson J.H. and Finar I.L.; (1978), J.Chem.Soc., 23,108-112

2. Fehr T.; Kol W. and Tanko S.; (1989), Lancet,3(40),618

3. Dell H.D. and Fiedler J.; (1974), Fresenium Z.Chem., 270-278

4. Beltagy Y.A.; (1977), Zentrable.Pharm.Pharmakother., 116(9), 925-933

5. Salman S. and Bayrakdar N.; (1983), Eczacilik Bul., 25(2), 30-33

6. Aboul Kheir A., El-Sadek M. and Baraka M.; (1987), Analyst, 112,1399-1403 
7. Salem H. and Aboul Kheir A., (1995), Anal.Lett.,20(10), 1833-1843

8. Agrawel Y.K.; (1980), Sci.Cult.,46(8),309-311

9. Pryakhim O.R. and Vdoviko V.A., (1981), Khim.Farm.Zh. ,15(12),93-95

10. Dell H.D. and Kamp R., (1970), Arch.Pharm.,303,785

11. Grigoreva A.S. and Konakhovich N.F.,(1982),Zh.Neorg (Khim),27(5), 1207-1215

12. Vinnikova A.V., (1980), Farm.Zh (Kiev), 1,32,6

13. Hassan S.M. and Shaba S.A., (1984), Pharmazie, 39(10),691- 693

14. Issa A.S., Beltagy Y.A., Kassem M.G. and Dabees H.G.(1985), Talanta, 32(3),209-211

15. Salem H. and Aboul Kheir A., (1995), Zag.J.Pharm.Sci , 4(2), 49-56

16. Hu Z.N. and Yu G.L., (1988), Nanjing Yaoxueyan Xucbao, 14(3), 17-22

17. Tjaden U.R., Bruijn E.A.and Lingeman H.,(1987), Chromatographia, 24(8), 707-714

18. The Britich Pharmacopeia, Her Majesty's Stationary Office, Cambridge(1980).

19. Clarke's(1986), Isolation and Identification of Drugs, second Edition

20. J.Rose, (1964), J.Advanced Physico-Chemical Experiments, Pitman London vol.54 